\title{
Development of a promising microbial platform for the production of dicarboxylic acids from biorenewable resources
}

Heeseok Lee ${ }^{1,2}$, Changpyo Han ${ }^{1}$, Hyeok-Won Lee', Gyuyeon Park ${ }^{1,2}$, Wooyoung Jeon ${ }^{1}$, Jungoh Ahn and Hongweon Lee ${ }^{1 *}$ (1)

\begin{abstract}
Background: As a sustainable industrial process, the production of dicarboxylic acids (DCAs), used as precursors of polyamides, polyesters, perfumes, plasticizers, lubricants, and adhesives, from vegetable oil has continuously garnered interest. Although the yeast Candida tropicalis has been used as a host for DCA production, additional strains are continually investigated to meet productivity thresholds and industrial needs. In this regard, the yeast Wickerhamiella sorbophila, a potential candidate strain, has been screened. However, the lack of genetic and physiological information for this uncommon strain is an obstacle that merits further research. To overcome this limitation, we attempted to develop a method to facilitate genetic recombination in this strain and produce high amounts of DCAs from methyl laurate using engineered $W$. sorbophila.
\end{abstract}

Results: In the current study, we first developed efficient genetic engineering tools for the industrial application of W. sorbophila. To increase homologous recombination (HR) efficiency during transformation, the cell cycle of the yeast was synchronized to the S/G2 phase using hydroxyurea. The HR efficiency at POX1 and POX2 loci increased from $56.3 \%$ and $41.7 \%$, respectively, to $97.9 \%$ in both cases. The original HR efficiency at URA3 and ADE2 loci was nearly $0 \%$ during the early stationary and logarithmic phases of growth, and increased to $4.8 \%$ and $25.6 \%$, respectively. We used the developed tools to construct W. sorbophila UHP4, in which $\beta$-oxidation was completely blocked. The strain produced $92.5 \mathrm{~g} / \mathrm{l}$ of dodecanedioic acid (DDDA) from methyl laurate over $126 \mathrm{~h}$ in 5 -I fed-batch fermentation, with a productivity of $0.83 \mathrm{~g} / \mathrm{l} / \mathrm{h}$.

Conclusions: Wickerhamiella sorbophila UHP4 produced more DDDA methyl laurate than C. tropicalis. Hence, we demonstrated that W. sorbophila is a powerful microbial platform for vegetable oil-based DCA production. In addition, by using the developed genetic engineering tools, this emerging yeast could be used for the production of a variety of fatty acid derivatives, such as fatty alcohols, fatty aldehydes, and $\omega$-hydroxy fatty acids.

Keywords: Wickerhamiella sorbophila, Alkane-assimilating yeast, Microbial platform, Dicarboxylic acid, Dodecanedioic acid, Vegetable oil, Genetic engineering tool

\footnotetext{
${ }^{*}$ Correspondence: hwlee@kribb.re.kr

${ }^{1}$ Biotechnology Process Engineering Center, Korean Research

Institute of Bioscience and Biotechnology (KRIBB), 30 Yeongudanji-ro,

Cheongwon-gu, Cheongju-si, Chungcheongbuk-do 28116, Republic

of Korea

Full list of author information is available at the end of the article
} 


\section{Background}

Industrial biotechnology, mainly known as white biotechnology in Europe, is a promising solution to replace the production of petroleum-based products that are widely used in daily life. Among various applications, the biotransformation of dicarboxylic acids (DCAs) from renewable resources has attracted much attention. DCAs are high value-added chemicals used as raw materials for a variety of products, such as polyamides (PAs), polyesters, perfumes, plasticizers, lubricants, and adhesives [1]. In particular, medium-chain DCAs (chain length $\geq 10$ ), such as sebacic acid $\left(\mathrm{C}_{10}\right)$ and dodecanedioic acid $\left(\mathrm{C}_{12}\right.$, DDDA), serve as precursors for PA 610 (nylon 6, 10) and PA 612 (nylon 6, 12) synthesis.

Alkane-assimilating yeasts are hosts for DCA biotransformation. Candida tropicalis with a strong $\omega$-oxidizing ability is a representative of this group of yeasts. These microorganisms convert terminal methyl groups of alkanes and fatty acids into carboxylic groups via $\omega$-oxidation and metabolize the corresponding fatty acids and DCAs via the $\beta$-oxidation pathway (Fig. 1). Several studies have focused on increasing DCA yield and productivity, for example, by blocking $\beta$-oxidation $[2,3]$ and enhancing $\omega$-oxidation $[4,5]$ in $C$. tropicalis. This led to the industrialization of the DCA bioprocess using paraffin (alkane) [6]. However, considering the limited availability of petroleum-based resources, such as alkanes, sustainable production of DCA from vegetable oil-based resources is necessary. Among these, methyl laurate $\left(\mathrm{C}_{12}\right)$ is an attractive sustainable resource. It is obtained from the esterification of coconut and palm kernel oil-rich in lauric acid $\left(\mathrm{C}_{12}\right)$-and is easily accessible for bioprocessing, since it is present in liquid form. Furthermore, medium-chain fatty acid methyl esters, including methyl laurate, are treated as by-products in the biodiesel industry, which relies on various vegetable oils to lower the cetane number associated with the ignition quality of fuel [7]. Consequently, DCA bioprocessing with vegetable oilbased feedstock as a starting material has been currently developed [8]. Unlike alkanes, however, biotransformation using vegetable oil-derived resources poses several difficulties. Cellular toxicity is one of the major obstacles that decrease the overall productivity of the bioprocess. In particular, medium-chain fatty acids (chain length $\leq 12$ ) are highly toxic compounds, which cause cell membrane stress, disruption of the electron transport system, acidification of the cytoplasm, and production of reactive oxygen species $[9,10]$. Medium-chain fatty acid methyl esters, such as methyl decanoate and methyl laurate, are hydrolyzed by extracellular lipases or esterases during the conversion phase and the resulting fatty acids cause cellular toxicity [11]. Because of its toxicity, various concentrations of DCA are produced, depending on the carbon chain length of fatty acids or that of methyl esters (Table 1).

We previously isolated a novel alkane-assimilating yeast Wickerhamiella sorbophila from wastewater of a petrochemical factory and attempted to use it to produce DDDA using methyl laurate [12]. The growth of $W$. sorbophila strain capable of $\omega$-oxidation in the presence of mixed fatty acid methyl esters $\left(\mathrm{C}_{10}-\mathrm{C}_{16}\right)$ was more stable than that of $C$. tropicalis and Yarrowia lipolytica [12]. Furthermore, it is a haploid and nonpathogenic yeast, with the associated advantages of genetic engineering and industrial safety [12]. Recently, whole-genome sequencing of $W$. sorbophila was completed, allowing easy access to the genetic information (https://www.ncbi. nlm.nih.gov/nuccore/NDIQ00000000.1/). Therefore, this emerging yeast is expected to greatly facilitate DCA production from fatty acid methyl esters, a vegetable oilderived resource.

Wickerhamiella sorbophila was first isolated as a culture contaminant from washings of ion-exchange resins from a guanine monophosphate manufacturing plant [13]. Since its discovery, W. sorbophila has rarely been investigated, except for some short studies on its production of lactone [14] and chiral R-amino alcohol [15]. Here, we first described the development of effective genetic engineering tools for industrial application of $W$. sorbophila. To facilitate genetic engineering, selectable antibiotic-resistance markers were explored and used to remove target genes. To increase the probability of gene insertion into the target locus, the cell cycle of yeast was synchronized to the S/G2 phase, during which homologous recombination (HR) frequently occurs, for yeast transformation. Finally, we developed an engineered $W$. sorbophila strain with a blocked $\beta$-oxidation pathway and applied it to the biotransformation of DCA from methyl laurate.

\section{Results and discussion \\ Cell growth in the presence of antibiotics}

Genetic manipulation is essential for the development of industrially competent strains. Despite the fact that the newly isolated $W$. sorbophila strain was a strong candidate for DCA production, biological information for genetic engineering of this strain is lacking. As a basic step for the development of genetic engineering tools, antibiotics for use of selectable markers in W. sorbophila were investigated. We evaluated cell growth in the presence of several antibiotics that are primarily used in eukaryotic genetic engineering (Fig. 2). No inhibitory effect on cell growth was observed with blasticidin $S$ and puromycin. Zeocin, hygromycin B, and G418 exerted a slight inhibitory effect, but cell growth was still observed even at high concentrations. However, nourseothricin 


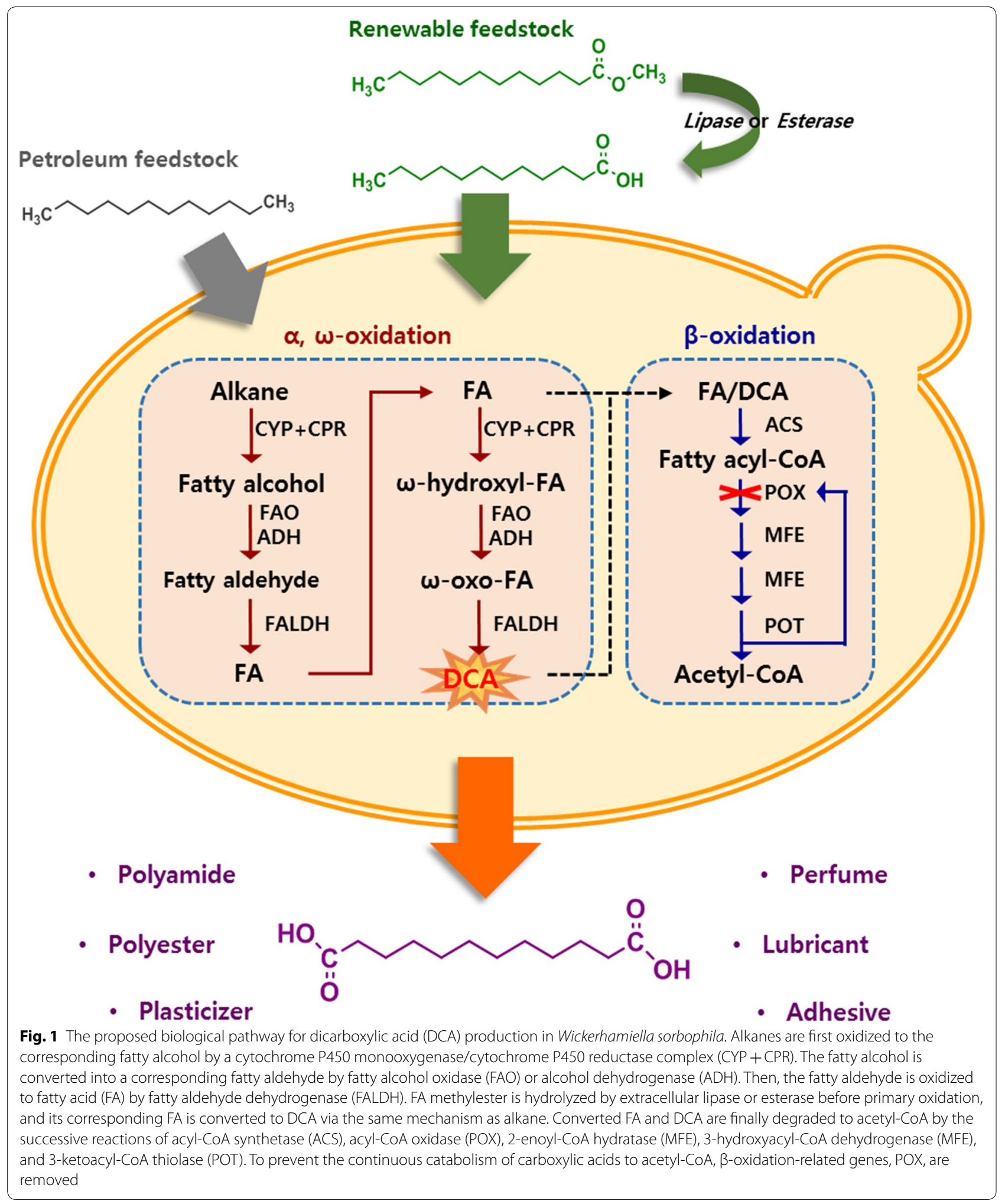


Table 1 Studies investigating the biotransformation of medium-chain DCAs from alkanes, fatty acids, and fatty acid methyl esters

\begin{tabular}{|c|c|c|c|c|}
\hline Strain & Substrate & Analytical method & $\mathrm{DCA}(\mathrm{g} / \mathrm{l})$ & References \\
\hline \multicolumn{5}{|l|}{ Petroleum-based resources } \\
\hline C. tropicalis ATCC 20962 & Dodecane $\left(C_{12}\right)$ & GC & $140^{\mathrm{a}}$ & [2] \\
\hline C. viswanathii ipe-1 & Dodecane $\left(C_{12}\right)$ & pH titration & 129.7 & [51] \\
\hline C. tropicalis CZ-15 & Tridecane $\left(C_{13}\right)$ & pH titration & 98 & [3] \\
\hline C. tropicalis CGMCC 356 & Tridecane $\left(C_{13}\right)$ & pH titration & 153 & [34] \\
\hline Y. lipolytica H222 $\triangle \mathrm{PoF}$ & Dodecane $\left(C_{12}\right)$ & GC & 11 & {$[52]$} \\
\hline Y. lipolytica MTLY 37 & Dodecane $\left(C_{12}\right)$ & GC & 8 & [53] \\
\hline Y. lipolytica MTLY 37 & Tetradecane $\left(\mathrm{C}_{14}\right)$ & GC & 2 & [53] \\
\hline \multicolumn{5}{|c|}{ Vegetable oil-based resources } \\
\hline C. tropicalis mutant ${ }^{b}$ & Methyl decanoate $\left(C_{10}\right)$ & GC & 34.5 & [11] \\
\hline C. tropicalis ATCC 20962 & Methyl laurate $\left(\mathrm{C}_{12}\right)$ & GC & 66 & {$[35]$} \\
\hline C. tropicalis ATCC 20962 & Methyl myristate $\left(C_{14}\right)$ & GC & $210^{\mathrm{a}}$ & [2] \\
\hline C. cloacae FERM-P736 & Lauric acid $\left(C_{12}\right)$ & GC & 5 & [54] \\
\hline W. sorbophila UHP4 & Methyl laurate $\left(C_{12}\right)$ & GC & 92.5 & This work \\
\hline
\end{tabular}

a Concentration calculated based on the initial volume

b Strain tolerant to decanoic acid derived from C. tropicalis ATCC 20962

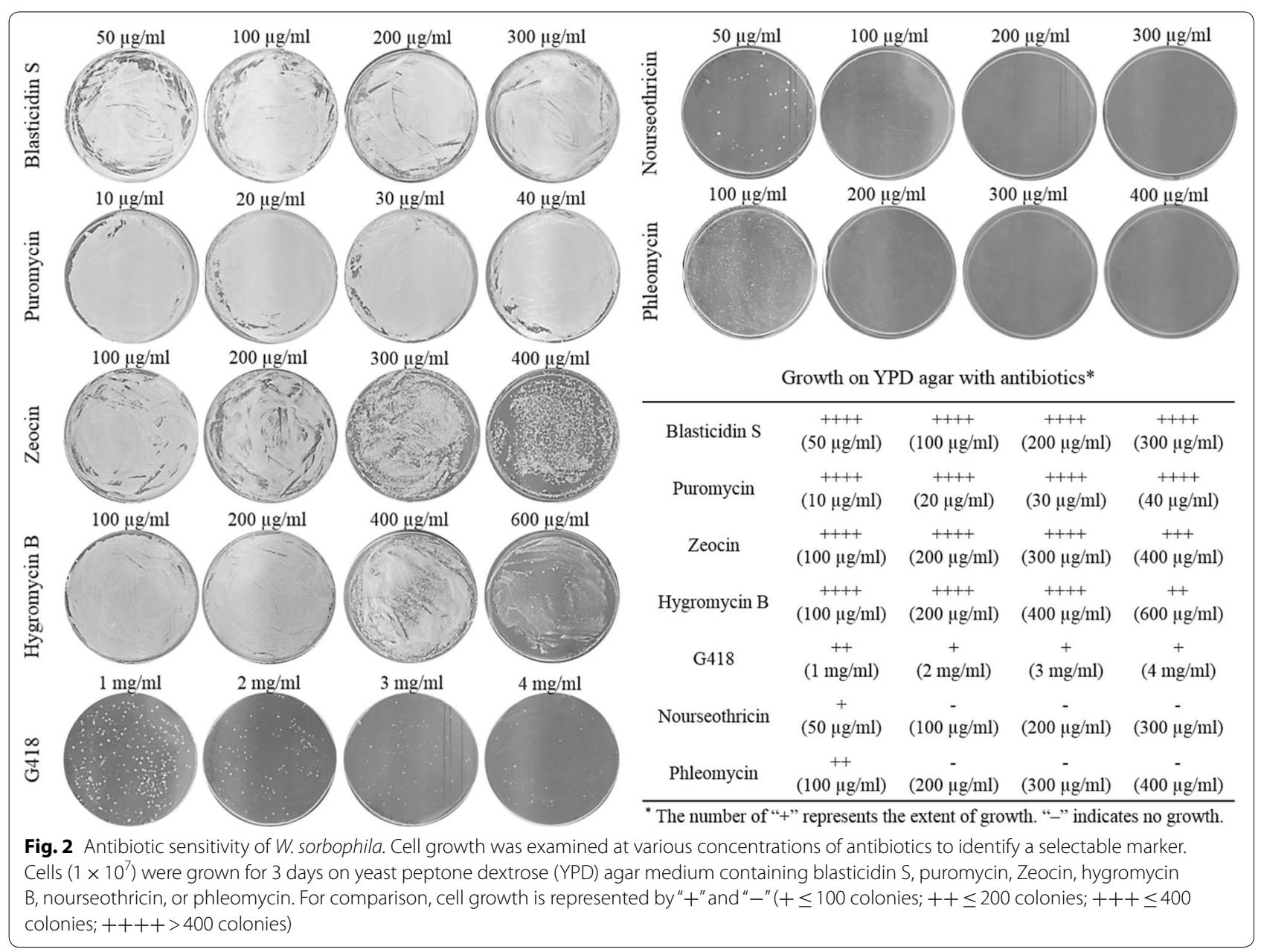


and phleomycin totally inhibited cell growth at 100 and $200 \mu \mathrm{g} / \mathrm{ml}$, respectively. Streptomyces noursei nat 1 and Streptoalloteichus hindustanus ble genes reportedly confer resistance to nourseothricin and phleomycin, respectively $[16,17]$. These genes were consequently used as selectable markers for W. sorbophila.

\section{Heterologous expression of nat 1 and ble genes}

Some yeasts, including the Candida species, decode CUG, a universal leucine codon, as serine. To enable heterologous expression of the marker genes, codon usage of W. sorbophila was analyzed. The analysis revealed that this strain might use standard genetic code (Additional file 1: Figure S1). Then, promoter and terminator sequences were investigated. While the use of heterologous promoter and terminator is often recommended to prevent interference caused by similarity of an endogenous DNA sequence during insertion of exogenous DNA into the chromosome, the stability or strength of expression is not guaranteed [18]. Hence, we next identified a homologous promoter sequence and a heterologous terminator sequence for heterologous gene expression. The 500-bp upstream region of the TEF gene was retrieved to identify a constitutive promoter in $W$. sorbophila. Translation elongation factor $1 \alpha$ gene, TEF, encoding the alpha subunit of the elongation factor complex, is involved in transferring the aminoacyl tRNA to the ribosome, and its promoter has been reported to constantly drive gene expression, regardless of the external environment and growth stage [19]. A heterologous terminator was obtained from the $C$. tropicalis GAPDH gene. To test the feasibility of using expression cassettes containing the nat1 or ble gene, we transformed W. sorbophila with the constructs by allowing linearized DNA (the resistance cassettes) lacking homology arms to be randomly inserted into the chromosome (Fig. 3). After 4 days of incubation, nourseothricin- or phleomycinresistant colonies appeared on the selection medium, and the inserted genes were identified by colony polymerase chain reaction (PCR) of the transformants. As shown in Fig. 3, the PCR products corresponding to the size of the inserted gene were detected in all resistant colonies tested, but not in the wild type. These observations indicated that the transcription system involving marker genes using a homologous promoter and heterologous terminator operated well in W. sorbophila.

\section{HR efficiency}

In eukaryotes, double-strand breaks (DSBs) induce two kinds of DNA repair mechanisms: HR and non-homologous end joining (NHEJ). HR allows the truncated $3^{\prime}$-end strand to recognize and replicate intact homologous double strands. NHEJ directly connects two DSBs by annealing short sequences near their end [20]. These two mechanisms occur competitively, and the balance varies depending on the cell cycle or species [21]. In yeast genetic engineering, HR has been used for insertion of external DNA at a desired position in the chromosome. Nonconventional yeasts, such as Y. lipolytica and Kluyveromyces marxianus, reportedly predominantly use NHEJ, resulting in random integration. To increase the HR rate in nonconventional yeast, most studies have focused on eliminating the function of the genes associated with the NHEJ pathway, such as the ones encoding Ku70/80 [22, 23] and DNA ligase IV [24]. However, the errors of the highly conserved DNA repair system impair the maintenance of genome integrity. Mutations in the DNA repair system increase the susceptibility to DNA damage, and the resulting increased mutation rate reduces cell viability $[25,26]$. To maintain an intact DNA repair system, we increased the HR rate by regulating the cell cycle. Recent studies have shown that the balance of HR and NHEJ shifts during the cell cycle [20,21] (Fig. 4a). In yeast and mammalian cells, since the accessibility of sister chromatids - the preferred template for $\mathrm{HR}$ repair-affects HR efficiency, HR use is elevated between the S and G2 phases of the cell cycle, during which the sister chromatids can be used [27]. Therefore, we deleted the target genes by synchronizing the cells in the $\mathrm{S}$ phase using $\mathrm{HU}$, an inhibitor of ribonucleotide reductase [28], and compared the HR efficiency in the resultant cells with that attained by other existing methods.

Prior to this experiment, the appropriate concentration of $\mathrm{HU}$ was determined. Microscopic analysis (Fig. 4b) revealed that cells at the $\mathrm{S} / \mathrm{G} 2 / \mathrm{M}$ phase coexisted at 0.05 and $0.1 \mathrm{M}$ of $\mathrm{HU}$, whereas cell division was inhibited at $0.4 \mathrm{M}$. Therefore, $\mathrm{HU}$ was used at $0.2 \mathrm{M}$ to arrest the cells at the S/G2 phase. To compare the HR efficiency depending on the cell growth conditions, deletion cassettes containing selectable markers were constructed and integrated into the URA3, ADE2, POX1, and POX2 loci, accordingly, depending on the growth stage (Additional file 1: Figure S2) (Table 2). ura3 or ade2 was eliminated using the ble marker; the resultant strains were named W. sorbophila U1 (ura3A) and W. sorbophila A1 (ade2A). pox1 or pox2 was eliminated using the URA3 marker; the resultant strains were named $W$. sorbophila UHP1 (pox1 $1 \Delta$ with URA3 harboring glu) and W. sorbophila UHP2 (pox2 $\Delta$ with $U R A 3$ harboring glu), respectively. In haploid yeast, the removal of genes with physiologically important functions is detrimental to cell growth and leads to a delay in the appearance of transformants [29]. To reduce the probability of selection errors, we supplemented the selection medium with the required nutrients, i.e., adenine and uracil, to support the growth of the desirable transformants. As shown in Table 2, HR 


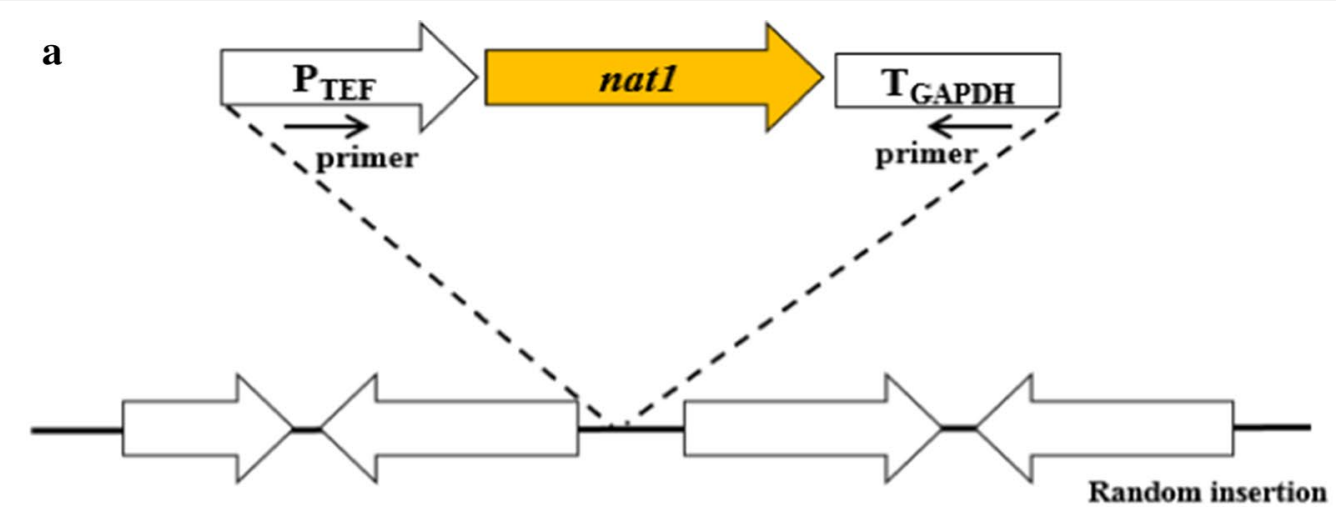

PCR-generated natl gene expression cassette
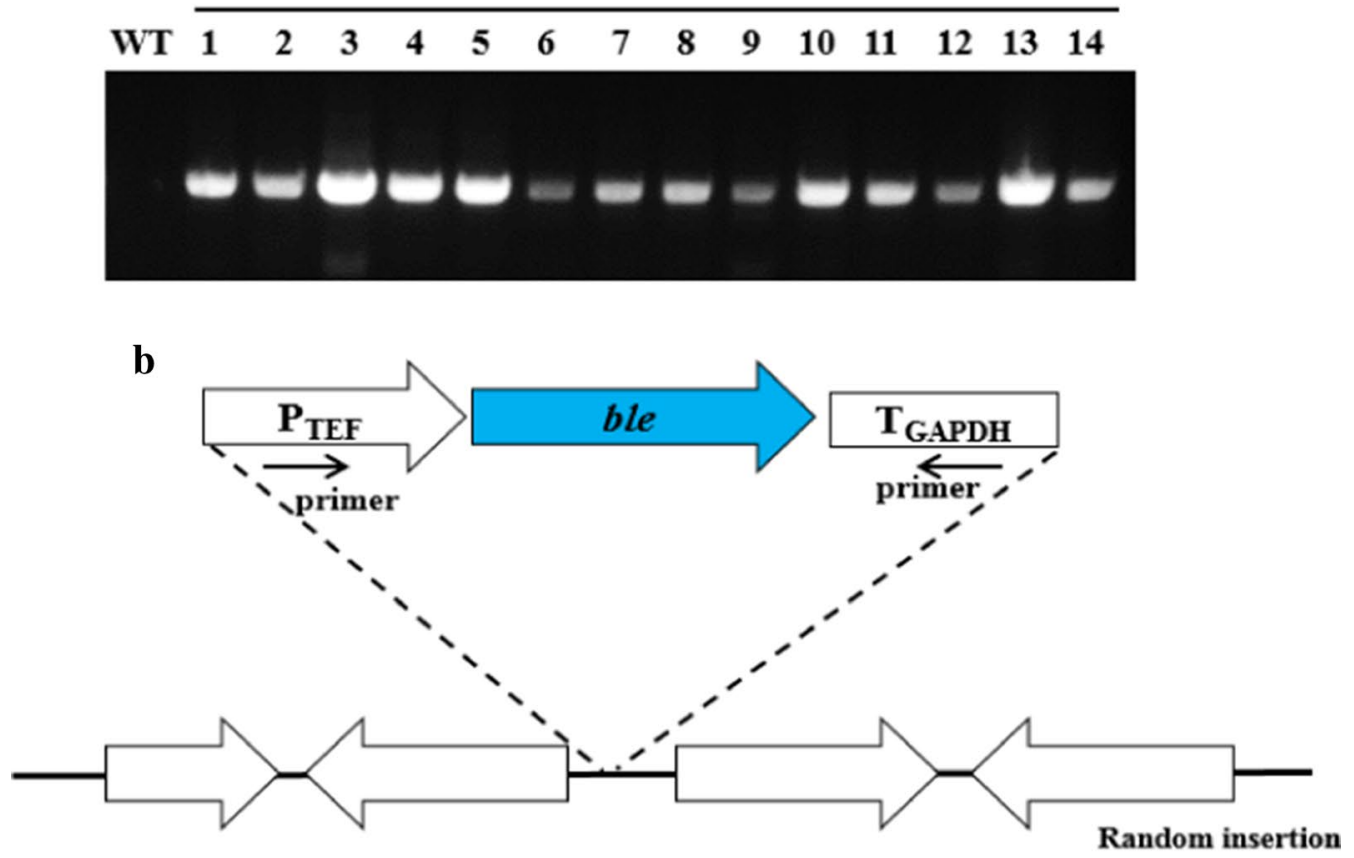

PCR-generated blel gene expression cassette

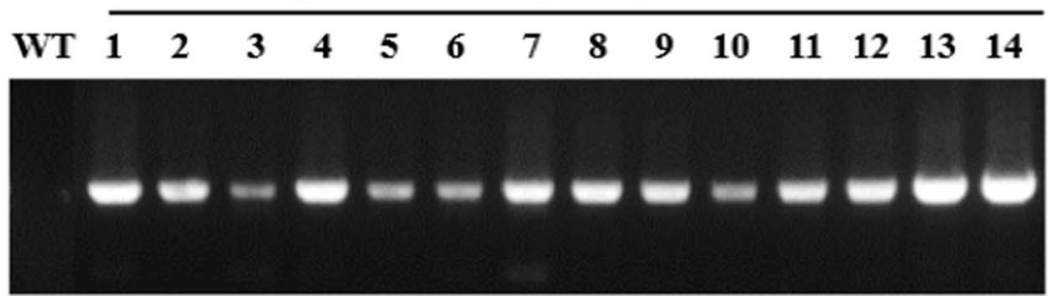

Fig. 3 Schematic representation of the expression cassettes and chromosome integration in W. sorbophila. The pUC18-nat1 (a) and pUC18-ble (b) cassettes, each containing the TEF promoter and GAPDH terminator, were PCR amplified using primers TEFp-F and GAPt-R and randomly inserted into the chromosome. The gel images show the results of yeast colony PCR using primers TEFp-F and GAPt-R. The sizes of the bands are $1.4 \mathrm{~kb}$ (a) and $1.2 \mathrm{~kb}(\mathbf{b})$ 


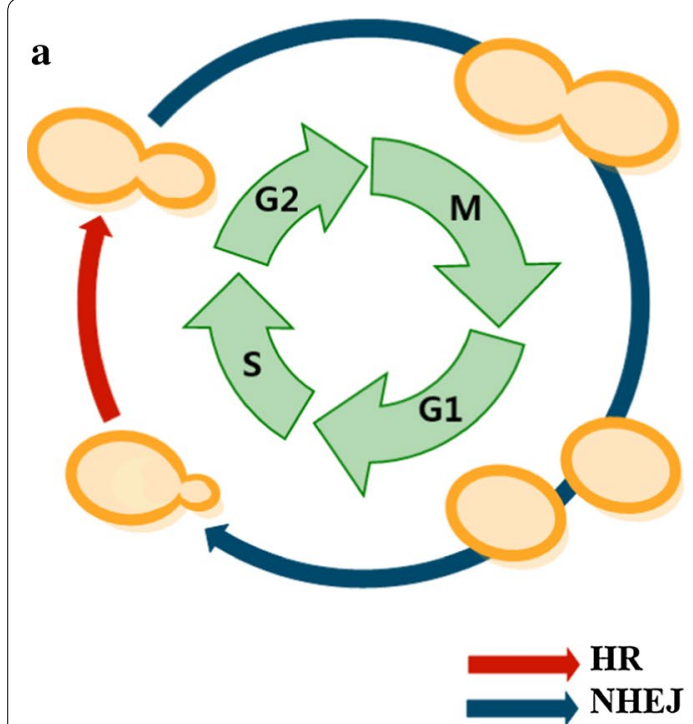

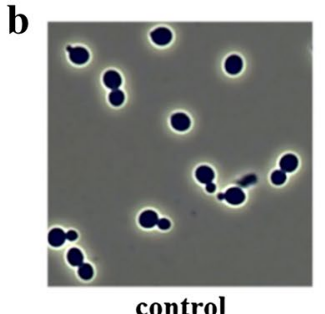

control

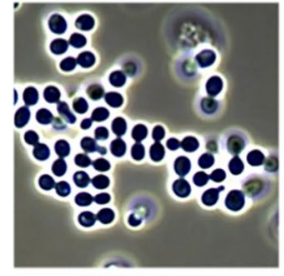

HU $0.05 \mathrm{M}$

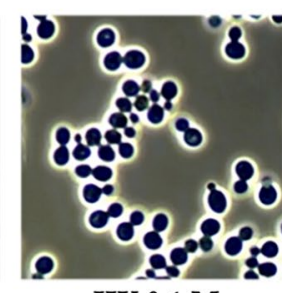

HU 0.1 M

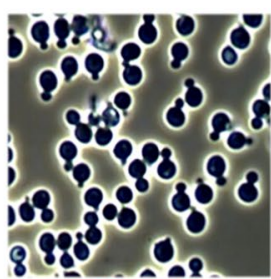

HU $0.2 \mathrm{M}$

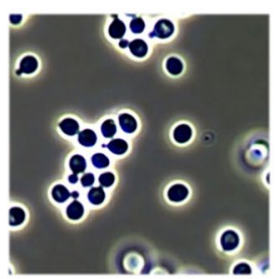

HU $0.4 \mathrm{M}$

Fig. 4 Cell synchronization using hydroxyurea (HU). In DNA repair, the HR and NHEJ mechanisms are competitive (a). HR is dominant at the S/G2 phase, and NHEJ is dominant at the G1/M phase. Micrographs of $W$. sorbophila treated with $H U$ at $0,0.05,0.1,0.2$, and $0.4 \mathrm{M}$ after $2 \mathrm{~h}$ (b)

Table 2 HR efficiency depending on the growth stage

\begin{tabular}{llllc}
\hline Growth stage & Strain & Target gene & Marker gene & HR efficiency \\
\hline Early stationary & DS02 & ADE2 & ble & $0 \%(1365)^{\mathrm{a}}$ \\
phase & DSO2 & URA3 & ble & $0 \%(186)^{\mathrm{a}}$ \\
& UHP1 & POX1 & URA3 & $56.3 \%(48)^{\mathrm{a}}$ \\
& UHP2 & POX2 & URA3 & $41.7 \%(48)^{\mathrm{a}}$ \\
Log phase & DS02 & ADE2 & ble & $1 \%(1470)^{\mathrm{a}}$ \\
& DS02 & URA3 & ble & $0 \%(186)^{\mathrm{a}}$ \\
& UHP1 & POX1 & URA3 & $81.3 \%(48)^{\mathrm{a}}$ \\
\multirow{5}{*}{ Sarrest } & UHP2 & POX2 & URA3 & $83.3(48)^{\mathrm{a}}$ \\
& DSO2 & ADE2 & ble & $25.6 \%(379)^{\mathrm{a}}$ \\
& DSO2 & URA3 & ble & $4.8 \%(186)^{\mathrm{a}}$ \\
& UHP1 & POX1 & URA3 & $97.9 \%(48)^{\mathrm{a}}$ \\
& UHP2 & POX2 & URA3 & $97.9 \%(48)^{\mathrm{a}}$ \\
\hline
\end{tabular}

${ }^{a}$ Number of transformants screened

frequency was highest in HU-treated cells, followed by those in the logarithmic and stationary phases of growth, in that order. HR efficiency at the POX1 and POX2 loci increased from $56.3 \%$ and $41.7 \%$, respectively, to $97.9 \%$ for both cases. The original HR efficiency at the $U R A 3$ and $A D E 2$ loci was nearly $0 \%$ in both early stationary and logarithmic phases, and increased to $4.8 \%$ and $25.6 \%$, respectively, after $\mathrm{HU}$ treatment.

The experiment revealed some distinct features of $W$. sorbophila. The strain showed various HR efficiencies depending on the targeted gene locus. The HR efficiency of genes essential for growth, such as ADE2 and URA3, was close to $0 \%$, but that of $P O X$ genes involved in fatty acid metabolism exceeded $40 \%$ (Table 2). This suggested the occurrence of HR hotspots on the genome of W. sorbophila. We successfully removed the ADE2 and URA3 genes, typically characterized by nearly $0 \% \mathrm{HR}$ efficiency, by regulating the cell cycle. Therefore, transformation involving $\mathrm{HU}$ is an effective and easy approach of increasing HR efficiency without permanently damaging the DNA repair system.

\section{Characterization of the putative WsPOX genes}

Acyl-CoA oxidase (EC:1.3.3.6.), which catalyzes the initial step in fatty acid $\beta$-oxidation, transfers hydrogen atoms in the $\mathrm{CH}-\mathrm{CH}$ group of acyl-CoA to molecular oxygen [30], resulting in the formation of trans-2-enoyl-CoA and $\mathrm{H}_{2} \mathrm{O}_{2}$. In alkane-assimilating yeasts, the deletion of $P O X$ genes prevents degradation of fatty acids, promoting $\omega$-oxidation of the terminal methyl group [2]. There are six $P O X$ genes in Y. lipolytica, some of which exhibit specific substrate affinity, depending on the carbon chain length [31,32]. Based on the whole-genome sequence of W. sorbophila, two putative $P O X$ genes with high amino acid sequence similarity to YALIOF10857g (the Y. lipolytica POX2 gene) were identified (POX1: B9G98_00908, 60\% sequence similarity; POX2: B9G98_04160, 52\% sequence similarity).

We characterized the putative $P O X$ genes by analyzing pox gene-deficient mutants. The pox 1 and pox 2 deletion strains were obtained using the methods described above. For the sequential disruption of the $P O X$ genes, the URA3 marker of $W$. sorbophila UHP1 was removed by HR between the both terminal glu sequences 
(pop-out) (W. sorbophila UHP3, pox1A without URA3 harboring $g l u$ ), and then the POX2 gene was eliminated by reusing the URA3 marker (W. sorbophila UHP4, pox $1 \Delta /$ pox $2 \Delta$ with $U R A 3$ harboring glu). As shown in Fig. $5 \mathrm{a}, \mathrm{b}$, the overall growth of mutants was reduced in comparison with that of the wild-type strain. The W. sorbophila UHP2 strain grew in the presence of all tested carbon sources. However, the W. sorbophila UHP1 strain exhibited unaltered growth on glucose, but not in the presence of medium-chain $\left(\mathrm{C}_{10}-\mathrm{C}_{12}\right)$ and long-chain $\left(\mathrm{C}_{14}-\mathrm{C}_{18}\right)$ alkanes. Only the POX1 gene-with a broad substrate spectrum-is expected to play an important role in fatty acid metabolism. An interesting phenomenon was reported previously, namely, that W. sorbophila simultaneously consumes various substrates during culture in the presence of mixed fatty acid methyl esters $\left(\mathrm{C}_{10}-\mathrm{C}_{16}\right)$ [12]. This may be associated with the broad substrate specificity of the product of the POX1 gene. The POX2 gene, however, is considered to be a pseudogene or involved in the metabolism of short-chain fatty acids. The DDDA conversion test (Fig. 5c) revealed that only W. sorbophila UHP1 and W. sorbophila UHP4 were able to convert dodecane to DDDA. W. sorbophila UHP1 and W. sorbophila UHP4 produced 9.38 and $9.12 \mathrm{~g} / \mathrm{l}$ of DDDA, respectively, and their conversion yields (mol/ mol) were $90.1 \%$ and $92.6 \%$, respectively. By contrast, the growth of $W$. sorbophila UHP2 was reduced during the first $24 \mathrm{~h}$, similarly to the other mutants, but eventually metabolized and used dodecane for cell growth. Hence, removal of the POX1 gene is essential for the accumulation of DDDA.

\section{Fed-batch fermentation for DDDA production}

In C. tropicalis, a well-known DCA-producing yeast, the fermentation process for DCA production has already been optimized [2, 33, 34]. The fermentation for DCA production is divided into growth and conversion stages, where the medium $\mathrm{pH}$ greatly affects fatty acid and DCA solubility, DCA excretion and cell viability $[11,34]$. During the conversion stage, acidic conditions $(=\mathrm{pH} 5.8)$ steadily promoted the cell growth, but DCA precipitates were formed and interfered with the process [35]. In the resting cells, a greater amount of DCA was released at a higher $\mathrm{pH}$ [36]; however, in living cells, $\mathrm{pH}$ values above 8.2 reduced cell viability and DCA productivity [34]. Considering this, we performed fed-batch fermentation using W. sorbophila UHP4 (with completely blocked $\beta$-oxidation) and methyl laurate. The $\mathrm{pH}$ was adjusted to 5.5 for the initial $12 \mathrm{~h}$ period to obtain high cell density, after which the $\mathrm{pH}$ was increased to $7.2-8.0$

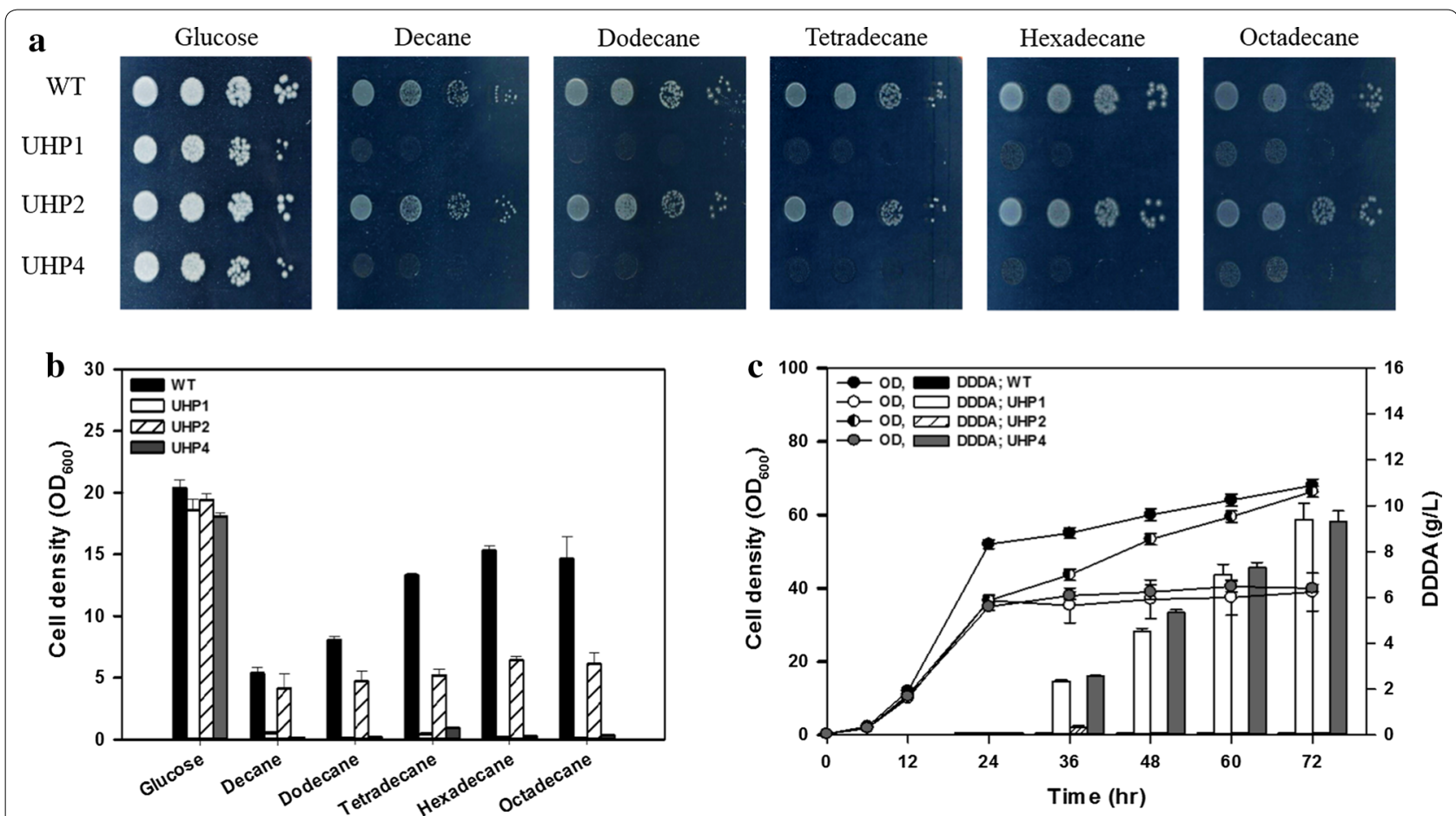

Fig. 5 Characterization of WsPOX-deficient mutants. Growth of POX-deficient mutants on yeast nitrogen base (YNB) agar (a) and liquid (b) media containing various carbon sources (glucose, decane, dodecane, tetradecane, hexadecane, and octadecane). After 24-h growth, 1\% (v/v) dodecane was added for DDDA conversion (c). Error bars represent the standard deviation of three independents trials. The values represent the means 
to solubilize fatty acid and DCA, and to promote DCA secretion (as described in detail in "Methods").

DCA conversion is initiated by cytochrome P450 monooxygenase (CYP); members of the CYP family are alkane-inducible in alkane-assimilating yeasts [37-39]. In C. tropicalis, the addition of methyl decanoate without the pre-activation of $\omega$-oxidation resulted in the accumulation of decanoic acid and directly affected cell viability [11]. Thus, prior to methyl laurate addition, $1 \%(\mathrm{v} / \mathrm{v})$ dodecane of the culture was added to pre-activate the $\omega$-oxidation pathway of $W$. sorbophila. In addition, Tween 80 , a nonionic surfactant esterified with polyethoxylated sorbitan and oleic acid, was used to facilitate the uptake of dodecane. In various prokaryotic and eukaryotic microorganisms, cellular uptake of hydrophobic substrates is involved in several mechanisms, such as substrate solubilization by extracellular emulsifying agents, modification of the cell surface to facilitate adhesion [40], passive diffusion via the cell membrane [33], and transporter-mediated uptake [41]. In $C$. tropicalis, the alkane-binding affinity of glucosegrown cells was lower than that of alkane-grown cells due to the alteration of the cell wall components [42]; the uptake of alkane on glucose-grown cells showed a greater dependence on the emulsification of alkane than alkane-grown cells [42]. Based on these reports, $1 \%(\mathrm{v} / \mathrm{v})$ Tween 80 was added to dissolve dodecane in the culture medium. Even if Tween 80 was hydrolyzed, as observed in some yeasts [43], oleic acid resulting from Tween 80 cleavage is not expected to affect the amount of DDDA produced by the strain with blocked $\beta$-oxidation. Finally, $W$. sorbophila UHP4 produced $92.5 \mathrm{~g} / \mathrm{l}$ of DDDA over $126 \mathrm{~h}$, with the productivity and yield of $0.83 \mathrm{~g} / \mathrm{l} / \mathrm{h}$ and $0.86(\mathrm{~mol} / \mathrm{mol})$, respectively (Fig. 6b). This was 1.4 times higher than the fermentation data for C. tropicalis and methyl laurate (Table 1). Most studies with dodecane have reported higher values than those obtained in the current study; however, an accurate comparison was difficult because the DDDA concentration was determined by $\mathrm{pH}$ titration or calculated based on the initial volume (Table 1). In the absence of Tween 80, DDDA productivity was greatly reduced, almost by half (Fig. 6a). A detailed study of this phenomenon would aid the improvement of the W. sorbophila performance. Furthermore, alongside process optimization, future studies on biotransformation using fatty acid methyl esters with various carbon chain lengths would expand the scope for the application of this strain.

\section{Conclusions}

Currently, sustainable production of DCA is a major concern in industrial biotechnology. Although many studies have contributed to this field, the biotransformation of DCA from renewable resources has been hindered because of the cellular toxicity of fatty acids. Previously, we identified several positive aspects of DCA production-industrially and biologically-using a W. sorbophila strain [12]. Here, we developed a novel microbial platform for DCA production, overcoming the limitation of toxicity. Based on whole-genome sequence information for W. sorbophila, we developed and optimized genetic engineering tools. To increase HR efficiency during the yeast transformation process, the cell cycle was artificially fixed at the S/G2 phase. To prevent the metabolism of alkanes and fatty acids, putative $P O X$ genes were characterized and removed. Interestingly, only pox1-deficient strains produced DDDA, suggesting that the $P O X 1$ gene plays a major role in $\beta$-oxidation. In 5-l fed-batch fermentation with $W$. sorbophila UHP4, $92.5 \mathrm{~g} / \mathrm{l}$ of DDDA was produced from methyl laurate in $126 \mathrm{~h}$. In conclusion, the presented data demonstrated that $W$. sorbophila is a promising microbial platform for DCA production from vegetable oil-based resources. Furthermore, the developed genetic engineering tools will form the basis for future research for the production of various value-added oleochemicals derived from vegetable oil, together with traditional metabolic engineering strategies, to improve DCA productivity.

\section{Methods}

\section{Strains, materials, and growth conditions}

The strains used in the current study are listed in Table 3. The nat 1 and ble genes were synthesized by GenScript (Piscataway, NJ, USA) (Additional file 1: Table S1). YNB medium without amino acids, and yeast extract and peptone were purchased from Becton-Dickinson (Franklin Lakes, NJ, USA). Nourseothricin was purchased from BioVision (Milpitas, CA, USA). Blasticidin S, hygromycin $\mathrm{B}$, phleomycin, puromycin, and Zeocin were purchased from InvivoGen (San Diego, CA, USA). Adenine, uracil, $\mathrm{HU}$, alkanes, lauric acid, methyl laurate, DDDA, Tween 80 , and $\mathrm{N}, \mathrm{O}$-bis-trimethylsilyl-trifluoroacetamide were from Sigma-Aldrich (St. Louis, MO, USA). 5-Fluoroorotic acid (5-FOA) and tetradecanedioic acid were from TCI Chemical (Tokyo, Japan). Antifoam agent (adekanol LG-109) was from Adeka (Tokyo, Japan). All other chemicals were purchased from Junsei Chemical (Tokyo, Japan).

The yeast strains were routinely cultured at $30{ }^{\circ} \mathrm{C}$ in YPD medium. When required, the medium was supplemented with $100 \mathrm{mg} / \mathrm{l}$ adenine or $100 \mathrm{mg} / \mathrm{l}$ uracil. For 

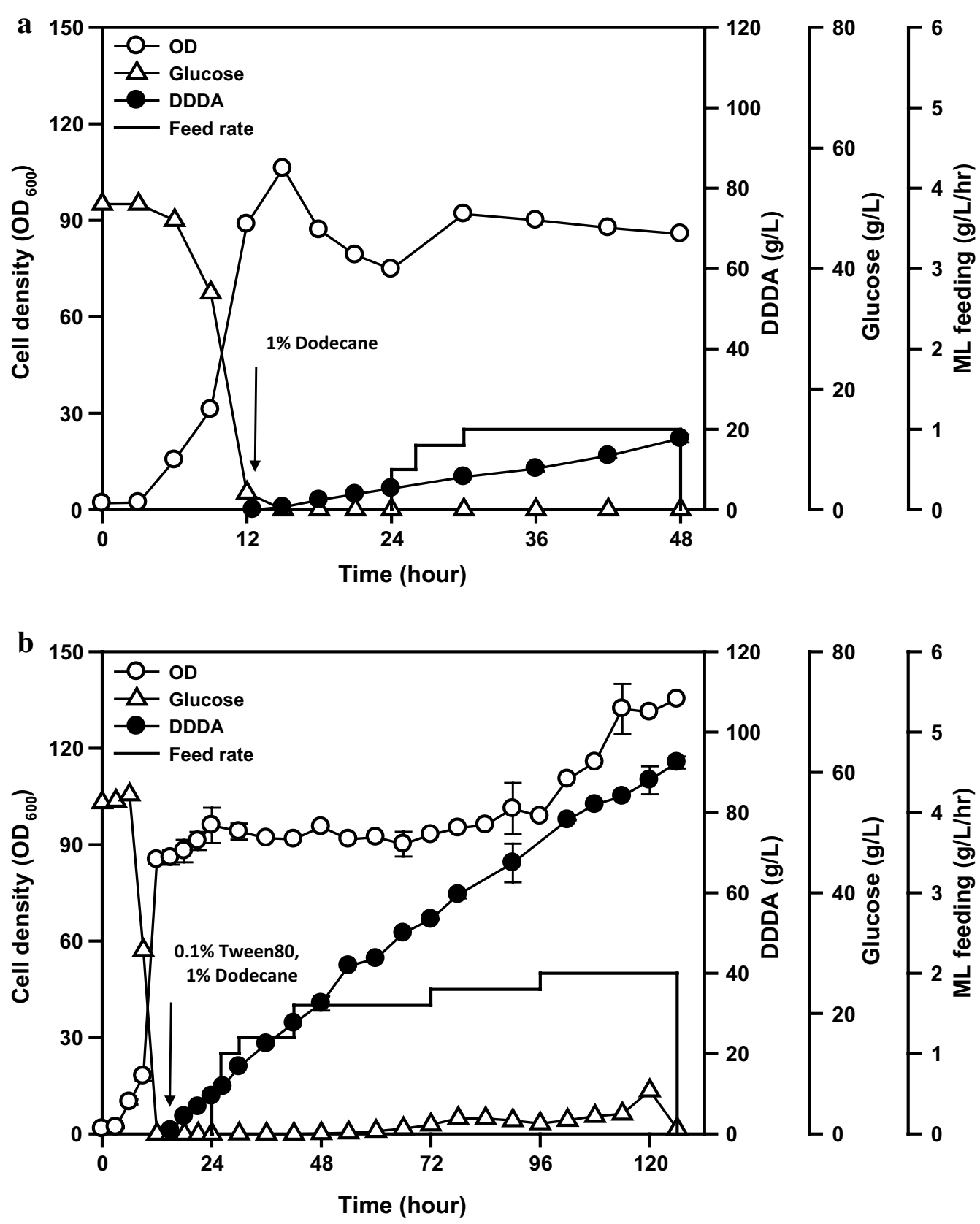

Fig. 6 Time profile of DDDA production in the absence (a) and presence of Tween 80 (b) by W. sorbophila UHP4 in 5-I fed-batch fermentation. For DDDA production, dodecane was added to induce $\omega$-oxidation-related enzymes, and methyl laurate was then fed continuously. ML methyl laurate. Error bars represent the standard deviation of three technical replicates. The values represent the means

the selection of antibiotic markers, $1 \times 10^{7}$ cells were spread on YPD agar medium containing $50-300 \mu \mathrm{g} / \mathrm{ml}$ blasticidin S, $10-40 \mu \mathrm{g} / \mathrm{ml}$ puromycin, $100-400 \mu \mathrm{g} / \mathrm{ml}$ Zeocin, 100-600 $\mu \mathrm{g} / \mathrm{ml}$ hygromycin B, 1-4 mg/ml G418, $50-300 \mu \mathrm{g} / \mathrm{ml}$ nourseothricin, or $100-400 \mu \mathrm{g} / \mathrm{ml}$ phleomycin. Antibiotic-resistant colonies were observed after incubation at $30^{\circ} \mathrm{C}$ for 3 days.
To analyze the growth of $W$. sorbophila strains, appropriate carbon sources $[20 \mathrm{~g} / \mathrm{l}$ glucose, $1 \%(\mathrm{v} / \mathrm{v})$ decane, $1 \%(\mathrm{v} / \mathrm{v})$ dodecane, $1 \%(\mathrm{v} / \mathrm{v})$ tetradecane, $1 \%(\mathrm{v} / \mathrm{v})$ hexadecane, or $1 \%(\mathrm{v} / \mathrm{v})$ octadecane] were added to YNB medium with $0.1 \%(\mathrm{v} / \mathrm{v})$ Tween 80 . In the case of solid YNB medium, alkanes were supplied in the vapor phase, as described previously [44]. Alkanes with fewer than 8 
Table 3 Strains used in the current study

\begin{tabular}{|c|c|c|}
\hline Strain & Genotype & Reference \\
\hline W. sorbophila DSO2 & Wild type & [12] \\
\hline W. sorbophila U1 & ura $3 \Delta::$ Sable & This work \\
\hline W. sorbophila A1 & ade2 $\triangle \cdots:$ Sable & This work \\
\hline W. sorbophila UHP1 & ura3 $\triangle$ pox $1 \triangle::$ glu-CtURA3-glu & This work \\
\hline W. sorbophila UHP2 & ura3 $\triangle$ pox2 $\triangle::$ glu-CtURA3-g/u & This work \\
\hline W. sorbophila UHP3 & ura3 $\triangle$ pox $1 \Delta:: g / u$ & This work \\
\hline W. sorbophila UHP4 & ura3 $\triangle$ pox $1 \Delta::$ glu pox $2 \Delta::$ CtURA3 & This work \\
\hline
\end{tabular}

or over 20 carbons were excluded because of their toxicity, volatility, or melting temperature. Pre-cultured cells were washed with YNB medium and then spotted onto agar medium in tenfold serial dilutions starting with $10 \mu \mathrm{l}$ of suspensions with $\mathrm{OD}_{600}$ of 0.1 .

\section{Prediction of codon usage}

The CUG codon usage of W. sorbophila was predicted using the fungal CUG codon-predicting site Bagheera [45]. The whole-genome sequence information was obtained from the GenBank database (Accession Number NDIQ00000001.1).

\section{PCR amplification}

The nat 1 and ble genes were PCR amplified using primers nat1-F and nat1-R, and ble-F and ble-R, respectively. A 500-bp sequence upstream of the TEF gene was amplified for use as a promoter from the genomic DNA of W. sorbophila DS02 using primers TEFp-F and TEFp$\mathrm{R}$. The 500-bp $5^{\prime}$ and $3^{\prime}$ homologous arms of the $A D E 2$, URA3, POX1, and POX2 genes were amplified for target gene disruption from the genomic DNA of $W$. sorbophila DS02 using primers ADE2 HR-F1, ADE2 HR-R2, ADE2 HR-F3, and ADE2 HR0-R4, for ADE2 disruption; URA3 HR-F1, URA3 HR-R2, URA3 HR-F3, and URA3 HR-R4, for URA3 disruption; POX1 infu-F1, POX1 infu$\mathrm{R} 2$, POX1 infu-F3, and POX1 infu-R4, for POX1 disruption; and POX2 infu-F1, POX2 infu-R2, POX2 infu-F3, and POX2 infu-R4, for POX2 disruption. The genomic sequence information was obtained from the GenBank database (Accession Number NDIQ00000000.1). A 300bp fragment downstream of the $G A P D H$ gene sequence was amplified for use as a terminator from the genomic DNA of strain ATCC 20962 using primers CtGAPt-F and CtGAPt-R; the genomic sequence information was obtained from the GenBank database (Accession Number HQ171163.1). A 1537-bp fragment of the glu gene was amplified for use as both flanking sequence of the URA3 marker from the genomic DNA of Bacillus subtilis using primers glu-F and glu-R. The genomic sequence information for that strain was obtained from the GenBank database (Accession Number CP020102.1).

Yeast colony PCR was performed to select transformants. Single colonies grown on the selection medium were suspended in $30 \mu \mathrm{l}$ of distilled water, treated with $20 \mathrm{U}$ of lyticase, and incubated for $1 \mathrm{~h}$ at $37{ }^{\circ} \mathrm{C}$. The resultant solution was directly used as a source of template for PCR. The insertion of selectable markers into transformants was confirmed by colony PCR using primers CiTEFp-F and CtGAPt-R. Disruption of target genes was first confirmed by colony PCR, and then by PCR with the genomic DNA isolated from the transformants, using primers URA3con-F, URA3con-R, POX1con-F, POX2con-F, and POXcon-R, as appropriate, specific for the sequence outside of the homologous arms. All primers used in the current study are listed in Additional file 1: Table S2.

\section{Plasmid construction}

To construct a heterologous gene expression cassette, the TEF promoter, nat1 gene, and GAPDH terminator were inserted into the ApaI/XhoI sites of pUC18 vector. The resulting plasmid was termed pUC18-nat1. The nat 1 gene in the pUC18-nat1 vector was then replaced by the ble gene, which resulted in plasmid pUC18-ble.

The $5^{\prime}$ and $3^{\prime}$ homologous arms of the $A D E 2$ gene were inserted into the $M l u \mathrm{I} / A p a \mathrm{I}$ and $B g l \mathrm{II} / E c o$ RI sites of the pUC18-ble vector, respectively. The resulting plasmid was termed pUC18-ADE2-ble. Homologous arms of the $U R A 3$ gene were inserted in the same way, resulting in a plasmid termed pUC18-URA3-ble.

For sequential disruption of the $W$. sorbophila $P O X$ genes, URA3 pop-out cassette was constructed according to a previously published protocol [46]. The W. sorbophila URA3 fragment was inserted into the $B a m \mathrm{HI} / B g l \mathrm{II}$ sites of pGEM-T easy vector, and the glu gene was inserted into the $B a m \mathrm{HI} / B g l \mathrm{II}$ sites at both ends of $U R A 3$, as a repeating sequence in the vector. The resulting plasmid contained the glu-URA3-glu cassette and was termed pGEM-gug. Then, the $5^{\prime}$ and $3^{\prime}$ homologous arms of the POX1 gene were inserted into the ApaI/SphI and $M l u$ I sites, respectively, of pGEM-gug vector, which was termed pGEM-POX1-gug. The homologous arms of the POX2 gene were inserted into the ApaI/SphI and $\mathrm{NdeI/SalI}$ sites, respectively, of pGEM-gug vector, resulting in the plasmid pGEM-POX2-gug.

\section{Transformation}

Wickerhamiella sorbophila was transformed using the lithium acetate method, with some modification [47]. After transformation of cells with $1 \mu \mathrm{g}$ of the linearized cassette, the cell pellet was suspended in $1 \mathrm{ml}$ of YPD and incubated for $2 \mathrm{~h}$ at $30{ }^{\circ} \mathrm{C}$ with shaking at $180 \mathrm{rpm}$. When 
required, the medium was supplemented with $100 \mathrm{mg} / \mathrm{l}$ adenine or $100 \mathrm{mg} / \mathrm{l}$ uracil. Then, the cells were spread on the selection medium and incubated for 5 days at $30{ }^{\circ} \mathrm{C}$. Ura3-deletion candidates were confirmed by colony PCR after primary counter-selection on 5-FOA agar medium [48]; ade2-deletion candidates were simply identified by red/white colony color [49]. Putative pox gene-deletion candidates were confirmed by colony PCR.

\section{Cell synchronization using $\mathrm{HU}$}

Synchronization of W. sorbophila cells was performed according to a previously published protocol [50]. Subsequently, subcultured cells were grown to $\mathrm{OD}_{600}=1$ in $50 \mathrm{ml}$ of YPD medium (when required, $100 \mathrm{mg} / \mathrm{l}$ adenine or $100 \mathrm{mg} / \mathrm{l}$ uracil was included in the medium), treated with $\mathrm{HU}$, and incubated for $2 \mathrm{~h}$ at $30{ }^{\circ} \mathrm{C}$ with shaking at $180 \mathrm{rpm}$. The synchronized cells were used for yeast transformation.

\section{Marker recycling}

To remove the URA3 marker from the W. sorbophila UHP1 genome, the cells were grown in $3 \mathrm{ml}$ of YPD medium overnight. Further, $100 \mu \mathrm{l}$ of the culture was spread on 5-FOA agar medium and incubated for 5 days at $30{ }^{\circ} \mathrm{C}$. The identity of the obtained colonies was confirmed by colony PCR.

\section{Flask cultivation for DCA production}

One loopful of cells was pre-cultured in a $15-\mathrm{ml}$ round tube with $3 \mathrm{ml}$ of YPD medium overnight. Then, $1 \mathrm{ml}$ of the culture was transferred to a $250-\mathrm{ml}$ baffled flask containing $20 \mathrm{ml}$ of YPDP medium $(10 \mathrm{~g} / \mathrm{l}$ yeast extract, $20 \mathrm{~g} / \mathrm{l}$ peptone, $30 \mathrm{~g} / \mathrm{l}$ glucose, and $\left.1.8 \mathrm{~g} / \mathrm{l} \mathrm{KH}_{2} \mathrm{PO}_{4}\right)$ and incubated at $30{ }^{\circ} \mathrm{C}$ with shaking at $200 \mathrm{rpm}$. After culturing for $24 \mathrm{~h}, 0.3 \mathrm{~g}(15 \mathrm{~g} / \mathrm{l}) \mathrm{K}_{2} \mathrm{HPO}_{4}$ and $0.2 \mathrm{ml}(1 \%$, v/v) of dodecane were added to the culture broth; $0.1 \mathrm{~g}(5 \mathrm{~g} / \mathrm{l})$ glucose was added, as $500 \mathrm{~g} / \mathrm{l}$ glucose solution, after 24 , $30,36,48$, and $60 \mathrm{~h}$.

\section{Fed-batch fermentation}

Fed-batch fermentation using the engineered W. sorbophila strain was performed according to a previously described protocol, with some modification [12]. One loopful of cells grown on YPD agar plates was inoculated in a $250-\mathrm{ml}$ baffled flask containing $20 \mathrm{ml}$ of YPD medium and incubated at $30{ }^{\circ} \mathrm{C}$ with shaking at $200 \mathrm{rpm}$ for $24 \mathrm{~h}$. The culture was transferred to a 2-l baffled flask containing $200 \mathrm{ml}$ of YPD medium and incubated at $30{ }^{\circ} \mathrm{C}$ and $200 \mathrm{rpm}$ for $24 \mathrm{~h}$. Subcultured cells were transferred to a 5-1 fermenter (CNS, Daejeon, Korea) with $2 \mathrm{l}$ of medium containing $50 \mathrm{~g} / \mathrm{l}$ glucose, $20 \mathrm{~g} / \mathrm{l}$ yeast extract, $8 \mathrm{~g} / \mathrm{l}\left(\mathrm{NH}_{4}\right)_{2} \mathrm{SO}_{4}, 2 \mathrm{~g} / \mathrm{K}_{2} \mathrm{HPO}_{4}$, $0.1 \mathrm{~g} / \mathrm{l} \mathrm{NaCl}, 0.1 \mathrm{~g} / \mathrm{l} \mathrm{CaCl}{ }_{2} \cdot \mathrm{H}_{2} \mathrm{O}$, and $0.5 \mathrm{ml}$ of antifoam agent. Temperature, medium $\mathrm{pH}$, and aeration were controlled at $30{ }^{\circ} \mathrm{C}, 5.5$, and $1 \mathrm{vvm}$, respectively. Dissolved oxygen was maintained above $30 \%$ by modulating the agitation speed between 200 and $900 \mathrm{rpm}$. After culturing for $12 \mathrm{~h}, 20 \mathrm{ml}(1 \%, \mathrm{v} / \mathrm{v})$ of dodecane and $2 \mathrm{ml}(0.1 \%, \mathrm{v} / \mathrm{v})$ of Tween 80 were added to the culture broth; glucose was continuously added at a rate of $2 \mathrm{~g} / \mathrm{l} / \mathrm{h}$; the medium $\mathrm{pH}$ was adjusted from 5.5 to 7.2 with $8 \mathrm{~N} \mathrm{NaOH}$, and then increased up to $7.8(\mathrm{pH} 7.2$ for the culture period of $12-24 \mathrm{~h}$; $\mathrm{pH} 7.4$ for $24-48 \mathrm{~h}$; $\mathrm{pH} 7.6$ for $48-96 \mathrm{~h}$; $\mathrm{pH} 7.8$ for $96-126 \mathrm{~h}$; and $\mathrm{pH} 8.0$ for $120-126 \mathrm{~h}$ ). After $24 \mathrm{~h}$, methyl laurate was continuously added at a rate of $0.5-2 \mathrm{ml} / \mathrm{l} / \mathrm{h}(0.5 \mathrm{ml} / \mathrm{l} / \mathrm{h}$ for the culture period of $24-26 \mathrm{~h} ; 1 \mathrm{ml} / \mathrm{l} / \mathrm{h}$ for $26-30 \mathrm{~h} ; 1.2 \mathrm{ml} / \mathrm{l} / \mathrm{h}$ for $30-42 \mathrm{~h} ; 1.6 \mathrm{ml} / \mathrm{l} / \mathrm{h}$ for $42-72 \mathrm{~h} ; 1.8 \mathrm{ml} / \mathrm{l} / \mathrm{h}$ for $72-96 \mathrm{~h}$; and $2 \mathrm{ml} / \mathrm{l} / \mathrm{h}$ for $96-126 \mathrm{~h}$ ) (Fig. $6 \mathrm{~b}$ ). The feeding rate was calculated based on the initial volume, and product concentration and productivity were calculated based on the end volume.

\section{Analytical methods}

Cell density, the concentrations of glucose, and DDDA in the culture broth were determined. Cell density was determined using an ultraviolet spectrophotometer (Uvikon XL; Secomam, Alès, France) by measuring the absorbance at $600 \mathrm{~nm}$. Glucose concentration was determined using a glucose analyzer (YSI 2700; YSI Life Sciences, Yellow Springs, OH, USA). DDDA was analyzed by gas chromatograph (Master GC; Dani Instruments, Cologno Monzese, Italy) equipped with an RTX-5 column (Restek, Bellefonte, PA, USA). A $50-\mu$ l aliquot of $6 \mathrm{~N} \mathrm{H}_{2} \mathrm{SO}_{4}$ was added to $100 \mu \mathrm{l}$ of culture broth, with tetradecanedioic acid used as an internal standard. The sample was then mixed with $400 \mu \mathrm{l}$ of diethyl ether. The upper solvent was separated and silylated with $\mathrm{N}, \mathrm{O}$ bis(trimethylsilyl)trifluoroacetamide. Each measurement was performed three times.

\section{Additional file}

Additional file 1: Table S1. The sequences of nat 1 and ble genes used in the current study. Table S2. Primers used in the current study. Figure S1. CUG codon prediction for Wickerhamiella sorbophila. The genome sequence uploaded in Bagheera was matched with sequences of 2071 proteins from 38 different protein families using TBALSTN [1]. Figure S2. Schematic representation of the deletion cassettes and chromosome integration in W. sorbophila. The pUC18-URA3-ble cassette was PCR-amplified using primers URA3-F and URA3-R, and inserted into the URA3 locus (a). The pUC18-ADE2-ble cassette was PCR-amplified using primers ADE2 HR-F and ADE2 HR-R, and inserted into the ADE2 locus (b). The pGEM-POX1-gug cassette was linearized by Hpal digestion and inserted into the POX 1 locus (c). The pGEM-POX2-gug cassette was linearized by Smal digestion and inserted into the POX2 locus (d). 


\section{Abbreviations}

5-FOA: 5-fluoroorotic acid; CYP: cytochrome P450 monooxygenase; DCA dicarboxylic acid; DDDA: dodecanedioic acid; DSB: double-strand break; GC: gas chromatography; HR: homologous recombination; HU: hydroxyurea; NHEJ: non-homologous end joining; PA: polyamide; PCR: polymerase chain reaction; YNB: yeast nitrogen base; YPD: yeast peptone dextrose.

\section{Authors' contributions}

$\mathrm{HoL}$ and JA designed the entire research project; HeL, CH, HWL, and GP executed the experimental work; HeL prepared the manuscript; HoL and WJ reviewed the manuscript; HeL revised the manuscript. All authors read and approved the final manuscript.

\section{Author details}

${ }^{1}$ Biotechnology Process Engineering Center, Korean Research Institute of Bioscience and Biotechnology (KRIBB), 30 Yeongudanji-ro, Cheongwon-gu, Cheongju-si, Chungcheongbuk-do 28116, Republic of Korea. ${ }^{2}$ Department of Bioprocess Engineering, KRIBB School of Biotechnology, Korea University of Science and Technology (UST), 217 Gajeong-ro, Yuseong-gu, Daejeon 34113, Republic of Korea.

\section{Acknowledgements}

Not applicable.

\section{Competing interests}

The authors declare that they have no competing interests.

\section{Availability of data and materials}

All datasets supporting the conclusions of this study are included in this published article (and its Additional file 1)

\section{Consent for publication}

Not applicable.

\section{Ethics approval and consent to participate}

Not applicable.

\section{Funding}

This research was supported by the Research Initiative Program (KGM4231713) of the Korea Research Institute of Bioscience and Biotechnology; Industry Core Technology Development Project (N10047873); and Global R\&D Project (N000677) of the Ministry of Trade, Industry, and Energy of Korea. The funding bodies did not play any role in the design of the study; the collection, analysis, and interpretation of data; and in writing the manuscript.

\section{Publisher's Note}

Springer Nature remains neutral with regard to jurisdictional claims in published maps and institutional affiliations.

\section{Received: 22 August 2018 Accepted: 30 October 2018}

Published online: 09 November 2018

\section{References}

1. Werner N, Zibek S. Biotechnological production of bio-based long-chain dicarboxylic acids with oleogenious yeasts. World J Microbiol Biotechnol. 2017;33(11):194

2. Picataggio S, Rohrer T, Deanda K, Lanning D, Reynolds R, Mielenz J, Eirich LD. Metabolic engineering of Candida tropicalis for the production of long-chain dicarboxylic acids. Nat Biotechnol. 1992;10(8):894.

3. Cao Z, Gao H, Liu M, Jiao P. Engineering the acetyl-CoA transportation system of Candida tropicalis enhances the production of dicarboxylic acid. Biotechnol J. 2006;1(1):68-74

4. Eschenfeldt WH, Zhang Y, Samaha H, Stols L, Eirich LD, Wilson CR, Donnelly MI. Transformation of fatty acids catalyzed by cytochrome P450 monooxygenase enzymes of Candida tropicalis. Appl Environ Microbiol. 2003;69(10):5992-9.

5. Craft DL, Madduri KM, Eshoo M, Wilson CR. Identification and characterization of the CYP52 family of Candida tropicalis ATCC
20336, important for the conversion of fatty acids and alkanes to a, w-dicarboxylic acids. Appl Environ Microbiol. 2003;69(10):5983-91.

6. Waltz E. Cathay industrial biotech. London: Nature Publishing Group; 2012

7. Knothe G. "Designer" biodiesel: optimizing fatty ester composition to improve fuel properties. Energy Fuels. 2008;22(2):1358-64.

8. Gustavsson M, Lee SY. Prospects of microbial cell factories developed through systems metabolic engineering. Microb Biotechnol. 2016:9(5):610-7.

9. Alexandre H, Mathieu B, Charpentier C. Alteration in membrane fluidity and lipid composition, and modulation of $\mathrm{H}^{+}$-ATPase activity in Saccharomyces cerevisiae caused by decanoic acid. Microbiology. 1996;142(3):469-75.

10. Liu P, Chernyshov A, Najdi T, Fu Y, Dickerson J, Sandmeyer S, Jarboe L. Membrane stress caused by octanoic acid in Saccharomyces cerevisiae. Appl Microbiol Biotechnol. 2013;97(7):3239-51.

11. Sugiharto YEC, Lee H, Fitriana AD, Lee H, Jeon W, Park K, Ahn J, Lee $\mathrm{H}$. Effect of decanoic acid and 10-hydroxydecanoic acid on the biotransformation of methyl decanoate to sebacic acid. AMB Express. 2018;8(1):75

12. Lee $H$, Sugiharto YEC, Lee $S$, Park G, Han C, Jang H, Jeon W, Park H, Ahn J, Kang K. Characterization of the newly isolated $\omega$-oxidizing yeast Candida sorbophila DS02 and its potential applications in long-chain dicarboxylic acid production. Appl Microbiol Biotechnol. 2017;101(16):6333-42

13. Nakase T. Three new asporogenous yeasts found in industrial waste water. Antonie Van Leeuwenhoek. 1975;41(1):201-10.

14. Świzdor A, Panek A, Milecka-Tronina N, KołekT. Biotransformations utilizing $\beta$-oxidation cycle reactions in the synthesis of natural compounds and medicines. Int J Mol Sci. 2012;13(12):16514-43.

15. Pscheidt B, Glieder A. Yeast cell factories for fine chemical and API production. Microb Cell Fact. 2008;7(1):25

16. Foureau E, Courdavault V, Simkin AJ, Sibirny AA, Crèche J, GiglioliGuivarc'h N, Clastre M, Papon N. Transformation of Candida guilliermondii wild-type strains using the Staphylococcus aureus MRSA 252 ble gene as a phleomycin-resistant marker. FEMS Yeast Res. 2013;13(3):354-8.

17. Shen J, Guo W, Köhler JR. CaNAT1, a heterologous dominant selectable marker for transformation of Candida albicans and other pathogenic Candida species. Infect Immun. 2005;73(2):1239-42.

18. Gueldener U, Heinisch J, Koehler G, Voss D, Hegemann J. A second set of loxP marker cassettes for Cre-mediated multiple gene knockouts in budding yeast. Nucleic Acids Res. 2002;30(6):e23.

19. Ahn J, Hong J, Lee H, Park M, Lee E, Kim C, Choi E, Jung J, Lee H. Translation elongation factor 1-a gene from Pichia pastoris: molecular cloning, sequence, and use of its promoter. Appl Microbiol Biotechnol. 2007:74(3):601-8.

20. Daley JM, Palmbos PL, Wu D, Wilson TE. Nonhomologous end joining in yeast. Annu Rev Genet. 2005;39:431-51.

21. Shrivastav M, De Haro LP, Nickoloff JA. Regulation of DNA double-strand break repair pathway choice. Cell Res. 2008;18(1):134

22. Verbeke J, Beopoulos A, Nicaud J-M. Efficient homologous recombination with short length flanking fragments in Ku70 deficient Yarrowia lipolytica strains. Biotechnol Lett. 2013;35(4):571-6.

23. Choo JH, Han C, Kim J-Y, Kang HA. Deletion of a KU80 homolog enhances homologous recombination in the thermotolerant yeast Kluyveromyces marxianus. Biotechnol Lett. 2014;36(10):2059-67.

24. Schorsch C, Köhler T, Boles E. Knockout of the DNA ligase IV homolog gene in the sphingoid base producing yeast Pichia ciferrii significantly increases gene targeting efficiency. Curr Genet. 2009;55(4):381-9.

25. Barnes G, Rio D. DNA double-strand-break sensitivity, DNA replication, and cell cycle arrest phenotypes of Ku-deficient Saccharomyces cerevisiae. Proc Natl Acad Sci USA. 1997;94(3):867-72.

26. Kretzschmar A, Otto C, Holz M, Werner S, Hübner L, Barth G. Increased homologous integration frequency in Yarrowia lipolytica strains defective in non-homologous end-joining. Curr Genet. 2013;59(1-2):63-72.

27. Mathiasen DP, Lisby M. Cell cycle regulation of homologous recombination in Saccharomyces cerevisiae. FEMS Microbiol Rev. 2014;38(2):172-84.

28. Rosenkranz HS, Levy JA. Hydroxyurea: a specific inhibitor of deoxyribonucleic acid synthesis. Biochim Biophys Acta. 1965;95(1):181-3. 
29. Chen Z, Sun H, Li P, He N, Zhu T, Li Y. Enhancement of the gene targeting efficiency of non-conventional yeasts by increasing genetic redundancy. PLoS ONE. 2013;8(3):e57952.

30. Wang HJ, Le Dall M-T, Waché Y, Laroche C, Belin J-M, Gaillardin C, Nicaud J-M. Evaluation of acyl coenzyme A oxidase (Aox) isozyme function in the $n$-alkane-assimilating yeast Yarrowia lipolytica. J Bacteriol. 1999;181(17):5140-8.

31. Mlíčková K, Luo Y, d'Andrea S, Peč P, Chardot T, Nicaud J-M. Acyl-CoA oxidase, a key step for lipid accumulation in the yeast Yarrowia lipolytica. J Mol Catal B Enzym. 2004;28(2-3):81-5.

32. Luo Y-S, Nicaud J-M, Van Veldhoven PP, Chardot T. The acyl-CoA oxidases from the yeast Yarrowia lipolytica: characterization of Aox2p. Arch Biochem Biophys. 2002;407(1):32-8.

33. Huf S, Krügener S, Hirth T, Rupp S, Zibek S. Biotechnological synthesis of long-chain dicarboxylic acids as building blocks for polymers. Eur J Lipid Sci Technol. 2011;113(5):548-61.

34. Liu S, Li C, Fang X, Cao ZA. Optimal pH control strategy for high-level production of long-chain a, $\omega$-dicarboxylic acid by Candida tropicalis. Enzyme Microb Technol. 2004;34(1):73-7.

35. Funk I, Rimmel N, Schorsch C, Sieber V, Schmid J. Production of dodecanedioic acid via biotransformation of low cost plant-oil derivatives using Candida tropicalis. J Ind Microbiol Biotechnol. 2017;44(10):1491-502.

36. Jiao $P$, Huang $Y$, Li S, Hua Y, Cao ZA. Effects and mechanisms of $\mathrm{H}_{2} \mathrm{O}_{2}$ on production of dicarboxylic acid. Biotechnol Bioeng. 2001;75(4):456-62.

37. Mauersberger S. Cytochromes $\mathrm{p} 450$ of the alkane-utilising yeast Yarrowia lipolytica. In: Barth G, editor. Yarrowia lipolytica. Microbiology Monographs, vol. 25. Berlin, Heidelberg: Springer; 2013. p. 227-62.

38. Sanglard D, Loper JC. Characterization of the alkane-inducible cytochrome P450 (P450alk) gene from the yeast Candida tropicalis: identification of a new P450 gene family. Gene. 1989;76(1):121-36.

39. Kogure T, Horiuchi $H$, Matsuda H, Arie M, Takagi M, Ohta A. Enhanced induction of cytochromes P450alk that oxidize methyl-ends of $n$-alkanes and fatty acids in the long-chain dicarboxylic acid-hyperproducing mutant of Candida maltosa. FEMS Microbiol Lett. 2007;271(1):106-11.

40. Beopoulos A, Chardot T, Nicaud J-M. Yarrowia lipolytica: a model and a tool to understand the mechanisms implicated in lipid accumulation. Biochimie. 2009;91(6):692-6.

41. Thevenieau F, Le Dall M-T, Nthangeni B, Mauersberger S, Marchal R, Nicaud J-M. Characterization of Yarrowia lipolytica mutants affected in hydrophobic substrate utilization. Fungal Genet Biol. 2007;44(6):531-42.
42. Käppeli O, Müller M, Fiechter A. Chemical and structural alterations at the cell surface of Candida tropicalis, induced by hydrocarbon substrate. J Bacteriol. 1978;133(2):952-8.

43. Buzzini P, Martini A. Extracellular enzymatic activity profiles in yeast and yeast-like strains isolated from tropical environments. J Appl Microbiol. 2002;93(6):1020-5.

44. Endoh-Yamagami S, Hirakawa K, Morioka D, Fukuda R, Ohta A. Basic helix-loop-helix transcription factor heterocomplex of Yas $1 p$ and Yas $2 p$ regulates cytochrome $\mathrm{P} 450$ expression in response to alkanes in the yeast Yarrowia lipolytica. Eukaryot Cell. 2007;6(4):734-43.

45. Mühlhausen S, Kollmar M. Predicting the fungal CUG codon translation with Bagheera. BMC Genom. 2014;15(1):411.

46. Yoon BH, Jeon WY, Shim WY, Kim JH. L-Arabinose pathway engineering for arabitol-free xylitol production in Candida tropicalis. Biotechnol Lett. 2011;33(4):747-53.

47. Ramon AM, Fonzi WA. Genetic transformation of Candida albicans. In: Cihlar RL, Calderone RA, editors. Candida albicans. Methods in Molecular Biology, vol. 499. Totowa, NJ: Humana Press; 2009. p. 169-74.

48. Akada R, Kitagawa T, Kaneko S, Toyonaga D, Ito S, Kakihara Y, Hoshida H, Morimura S, Kondo A, Kida K. PCR-mediated seamless gene deletion and marker recycling in Saccharomyces cerevisiae. Yeast. 2006;23(5):399-405.

49. Ugolini S, Bruschi CV. The red/white colony color assay in the yeast Saccharomyces cerevisiae: epistatic growth advantage of white ade8-18, ade2 cells over red ade2 cells. Curr Genet. 1996;30(6):485-92.

50. Tsakraklides V, Brevnova E, Stephanopoulos G, Shaw AJ. Improved gene targeting through cell cycle synchronization. PLOS ONE. 2015:10(7):e0133434.

51. Cao W, Liu B, Luo J, Yin J, Wan Y. a, w-Dodecanedioic acid production by Candida viswanathii ipe-1 with co-utilization of wheat straw hydrolysates and $n$-dodecane. Bioresour Technol. 2017;243:179-87.

52. Gatter M, Förster A, Bär K, Winter M, Otto C, Petzsch P, Ježková M, Bahr K Pfeiffer M, Matthäus F. A newly identified fatty alcohol oxidase gene is mainly responsible for the oxidation of long-chain $\omega$-hydroxy fatty acids in Yarrowia lipolytica. FEMS Yeast Res. 2014;14(6):858-72.

53. Smit MS, Mokgoro MM, Setati E, Nicaud J-M. a, w-Dicarboxylic acid accumulation by acyl-CoA oxidase deficient mutants of Yarrowia lipolytica. Biotechnol Lett. 2005;27(12):859-64.

54. Green KD, Turner MK, Woodley JM. Candida cloacae oxidation of long-chain fatty acids to dioic acids. Enzyme Microb Technol. 2000;27(3-5):205-11.
Ready to submit your research? Choose BMC and benefit from:

- fast, convenient online submission

- thorough peer review by experienced researchers in your field

- rapid publication on acceptance

- support for research data, including large and complex data types

- gold Open Access which fosters wider collaboration and increased citations

- maximum visibility for your research: over $100 \mathrm{M}$ website views per year

At BMC, research is always in progress.

Learn more biomedcentral.com/submissions 